\section{Acoustique Musicale}

(Marseilles, 27, 28, 29 Mai, 1959.) (Colloques Internationaux du Centre National de la Recherche Scientifique, No. 84.) Pp. 259. (Paris : Editions du Centre National de la Recherche Scientifique, 1959.) 3,400 francs.

GROM time to time the subject of musical acoustics 1 earns itself a colloquium. There was one recently in London (see Nature, 183, $1293 ;$ 1959) and others have taken place in Switzerland and the United States. The colloquium the proceedings of which are under review was more ambitious, since from its audience it could be justly called international and was conducted at Marseilles, surprisingly under the patronage of the Centre National de Recherche Scientifique. Such gatherings usually attract a number of scientists who are amateur musicians but few professional musicians. The organizers of this one were fortunate in collecting an audience nearly equally divided between the two types. The papers presented indeed, with a few exceptions, fell into two classes, those concerned with the acoustics of musical instruments (the scientific) and those with intonation and musical scales (the arithmetic, if the writer of this notice may be pardoned for using the term). A surprising amount of 'academic' discussion was engendered concerning the effects of changing an interval in a scale by a small fraction say, a few cents, academic because real singers and instrumentalists do not hold intonation to such a precision.

One may have doubts whether this subject is an art or a science, but many readers of these proceedings will gain a refreshing insight into the range of interest and activity covered by the term 'musical acoustics'.

E. G. RichaRdson

Biological Sciences

Vol. 2. Edited by J. G. Bugher, J. Coursaget and J. F. Loutit. (Progress in Nuclear Energy, Series 6.) Pp. $x+422+x i i$. (London and New York : Pergamon Press, 1959.) 105s. net.

7 HIS is an editorial selection of thirty-five papers out of the many presented to some of the biological and medical sessions of the Second Conference on the Peaceful Uses of Atomic Energy (1958). The subjects range from the distribution of labelled drugs in the body, to radiation-induced ageing in mice and induced mutations in polygenic systems. The reviewer ean only apply a further arbitrary selection. A remarkable paper by Barnes, Ford, Gray and Loutit reports the discovery that repopulation of hæmopoietic tissue by host cells in radiation-chimæra is often effected by a very few clones of cells, sometimes recognizable by chromosomal 'markers'.

Ullberg gives some beautiful examples of how the distribution, Iocalization and metabolism of certain (labelled) drugs can be followed by auto-radiography ; Muller reviews the recent contributions of Drosophita work to the knowledge of radiation-induced mutation.

General papers deal with the 'ageing' effects of radiations and, more generally, with the effects on the life-span. Others deal with agents modifying the biological effects of radiations, with the elimination of radioactive substances from the body and with chemical effects of radiations on particular substances. A considerable proportion of the book is concerned with the induction of mutations.

The book is an indispensable- - though somewhat expensive-reference for laboratories in any way concerned with the biological effects of radiations.

G. Pontecorvo

\section{Tracer Applications for the Study of Organic} Reactions

By John G. Burr, Jr. Pp. $x+291$. (New York: Interscience Publishers, Inc. ; London: Interscience Publishers, Ltd., 1957.) 7.50 dollars.

$\mathrm{N}$ this book the author has attempted to present the evidence obtained by the use of isotopic tracers in the study of organic reaction mechanism. A very wide field has been covered, and in some sections, for example, that on migration aptitudes, a valuable critical discussion has been included. It is rather a pity that this standard has not been adhered to throughout and the work thus becomes rather uneven. Its main value lies in the full literature index which forms a most useful guide to further reading on the many reactions discussed. The literature coverage (up to early 1953) makes certain sections out of date at the time of writing but the author feels that the book will be of some value to the advanced worker who wishes to use it as a literature source book. Valuable appendixes on the subjects of reaction mechanism and handling of isotopic tracers, together with an additional list of references covering the period 1953-1954, are also included.

A. I. Sсотт

\section{Index of Chemistry Films}

A Comprehensive List of Films and Filmstrips on Chemistry and Related Topics. Pp. ix +150 . (London: Royal Institute of Chemistry, 1959.) $5 s$.

7 HE object of this publication is to provide an up-to-date guide to the eight hundred or so films and two hundred or so film strips on chemical topics that are available in Great Britain. The films are classified according to subjects. Brief information is supplied on how any film may be obtained, on its length, gauge, essential contents and, where known, suitability for particular audiences. especially schools. This is a most valuable pamphlet. the existence of which should be made widely known so that fuller use can be made by schools and other institutions of the extensive amount of available material.

\section{Royal Institute of Chemistry Monographs for Teachers}

No. 1: Principles of Electrolysis. By Prof. C. W. Davies. Pp. v+30. 3s. 6d. No. 2: Principles of Oxidation and Reduction. By Dr. A. G. Sharpe. Pp. $\mathrm{v}+30$. 3s. $6 d$. (London: Royal Institute of Chemistry, 1959.)

AVERY student who goes up to university soon encounters the frustrating experience of having to 'unlearn' something of what he has been taught at school. There may well be something to be said for the educational value of varied approaches and the discarding, on the basis of more adequate arguments, of material acquired parrot-fashion at a younger age. There can be no doubt, however, that such lessons ought to be kept to a minimum and that time at school is in general more wisely spent on the teaching of fundamentals on a sound basis.

With this object in mind, the Royal Institute of Chemistry have now begun the issue of pamphlets on some of the more advanced topics of the school chemistry syllabus, to provide a short refresher course for teachers. The venture deserves every success and has had a good send-off with the two pamphlets issued so far. V. GoLD 